\title{
El portal de promoción de buenas prácticas en Europa del OEDT. Un instrumento de diseminación vía Internet
}

\section{EMCDDA Best Practice Promotion in Europe: an Internet based dissemination tool}

\author{
| Marica Ferri; Alessandra Bo
}

European Monitoring Centre for Drugs and Drug Addiction (EMCDDA), Lisbon, Portugal

Send correspondence to:

Marica Ferri

European Monitoring Centre for Drugs and Drug Addiction (EMCDDA)

Cais do Sodré, 1249-289 Lisbon, Portugal

Marica.Ferri@emcdda.europa.eu

Tel. (351) 211210343

Fax (351) 213584441

\section{Resumen}

Las buenas prácticas resultan de la mejor aplicación de la evidencia disponible en relación con las actividades en curso en materia de drogas. El Observatorio Europeo de las Drogas y las Toxicomanias (OEDT) ha creado una herramienta basada en la web destinada a combinar adecuadamente las evidencias científicas y las prácticas actuales en el campo de las drogodependencias. Más allá del propósito de dar difusión a las evidencias existentes, el objetivo es también compartir las buenas prácticas entre los paises europeos.

Para sintetizar la evidencia existente se toma como referencia los métodos de la Colaboración Cochrane (Grupo de drogas y alcohol) y el Grading of Recommendations Assessment, Development and Evaluation (GRADE). En febrero de 2013, el portal incluye cuatro módulos de la efectividad de las intervenciones de reducción de la demanda, una colección de proyectos europeos sobre prevención, tratamiento, reducción de daños y reinserción social y un inventario de directrices y normas europeas incluyendo un banco de instrumentos para evaluar las intervenciones (http://www.emcdda. europa.eu/best-practice).

Los resúmenes sobre las evidencias se presentan en un lenguaje sencillo y directo e incluye una breve explicación acerca de los datos que dan soporte a estas evidencias, pero no proporcionan recomendaciones especificas. El principal reto futuro del portal de promoción de buenas prácticas de la OEDT es llegar a ser un servicio de referencia para aquellos interesados en aplicar las buenas prácticas. El portal debe convertirse en una plataforma donde encontrar todo que se necesita para la implementación exitosa de las buenas prácticas (manuales, materiales de formación, guias para la evaluación y contactos para tutorias).

Palabras clave: OEDT, buenas prácticas, diseminación basada en el web, evidencia, toma de decisiones.

\section{Abstract}

Best practice is the best application of available evidence to current activities in the drugs field. The European Monitoring Centre for Drugs and Drug Addiction (EMCDDA) created a web-based tool aimed at bridging together scientific evidence and current practices in the drug addiction field. Beyond dissemination of evidence, the scope is to share best practice among the European countries.

The synthesis of the evidence is based on the methods of the Cochrane collaboration (the Drugs and Alcohol Group) and the Grade working group. As of February 2013 the portal encompasses four modules on the effectiveness of demand reduction interventions, a collection of European projects on prevention, treatment, harm reduction and social reintegration and an inventory of European Guidelines and Standards including a bank of instruments to evaluate interventions (http://www.emcdda.europa.eu/bestpractice).

The summaries of evidence are presented in a plain language format and include brief explanation of the measures of effect supporting the evidence, but do not provide specific recommendations. The main future challenge of EMCDDA's best practice promotion is to become a service for those willing to implement best practice. The Best Practice Portal should become a platform where to find all is needed for successful implementation (handbooks, training materials, guidelines for evaluation and contacts for mentoring).

Key Words: EMCDDA, best practice, web-based dissemination, evidence, decision making 
T he concept of evidence-based practice comes from the medical field where it was defined as "the conscientious, explicit, and judicious use of current best evidence in making decisions about the care of individual patients" (Sackett, Rosenberg, Gray, Haynes, \& Richardson, 1996). A similar concept was then transferred to the social and political sciences with the aim of helping people make well-informed decisions by developing, maintaining and disseminating systematic reviews in specific areas such as education, crime, justice and social welfare 1 . In the drug demand reduction field, evidence-based practice is geared to the use of scientific results to inform decisions in the areas of drug use prevention, treatment and harm reduction.

"Best practice" requires the careful integration of both scientific knowledge and implementation expertise to appropriately tailor the intervention to specific individuals and context. A best practice intervention should ultimately provide better outcomes than others and as a consequence to allow a more rational allocation of resources.

\section{EMCDDA Best Practice definition in Drug Demand Reduction}

A group of experts including the Chairman of the EMCDDA Management Board; members of the EMCDDA Scientific Committee; policymakers; and top-level researchers in the areas of treatment, prevention and harm reduction, discussed the results of a literature search and content analysis on the meaning of "best practice" in the scientific articles on drug demand reduction, to create an ad-hoc definition of best practice.

The group, convened at the EMCDDA premises in November 2010 agreed on the following definition:

'Best practice is the best application of available evidence to current activities in the drugs field.

Namely it consists of the following key concepts:

- The underlying evidence should be relevant to the problems and issues affecting those involved (professionals, policymakers, drug users, their families) as opposed to mere academic speculation;

- The methods should be transparent, reliable, transferable and all the relevant evidence should be considered in the classification process;

- The experience in implementation, adaptation and training should be systematically taken into account;

- The contextual factors should be studied by modelling different prevalence levels to assess the impact of an intervention on the population; and

- The evidence of effectiveness and feasibility of implementation should be considered within the broader decision-making process.'

\section{Best Practice Promotion}

The overall goal of the Best Practice Promotion strategy of the EMCDDA is to promote exchange of best practice in the drug field. To achieve such ambitious aim one key activity undertaken has been the development of an internet-based tool providing reliable information on the latest scientific evidence on demand reduction interventions as well as on the practical aspects of implementation.

Nowadays the general public, the practitioners as well as the patients have access to an amount of scientific information delivered in several user friendly formats. Besides electronic libraries and email alerts, other tools rapidly spreading are online Point-of-Care information services which can be defined as "web based compendiums designed to provide health professionals with comprehensive evidence condensed into easily digestible formats" ( Banzi, Moja, Pistotti, Facchini, \& Liberati, 2011a).

One of the most significant benefits of online point-ofcare tools is the pre-assessment of research findings and the friendly interfaces facilitating the usability of the data.

Key issues for the validity of such tools have been identified in recent reviews (Banzi, Liberati, Moschetti, Tagliabue, \& Moja, 2010). as clear formulations of literature retrievals, transparent methodology of ranking of the evidence, timely update of the information and explicit editorial processes.

Nevertheless, despite the growing amount of point-of-care services, no information is yet available on the impact of these tools on the actual practice improvement (Banzi et al., 2011b).

A brief survey undertaken by the authors of the present article has shown that drug addiction in current point-of-care services (such as Clinical Evidence, Best Practice, UpToDate, Dynamed) is covered in specific sub-sections mainly aimed at health professionals.

Drug addiction specific internet sites (such as Findings, Drugscope, National Treatment Agency (NTA); the National Institute of Drug Addiction (NIDA), Substance Abuse and Mental Health Service Administration (SAMSHA)) collect and publish high quality information with a specific focus on their own national context.

The EMCDDA Best Practice Portal aims to make available both digestible synthesis of evidence and examples of practices to a European wide audience, ranging from policy makers to practitioners and the general public. It benefits from the access to a European Network of Focal Points allowing the collection of a broad yet context specific implementation examples.

The Best Practice Portal (http://www.emcdda.europa.eu/ best-practice, figure 1.) currently contains evidence modules on prevention, treatment, harm reduction and social reintegration. The modules are biannually updated with new evidence, if available, and dates for last and next update are included in each module. Experience from practice is presented in a separate section and it includes an inventory of European standards and guidelines and a collection of real-life projects from 30 European countries (EDDRA database). 


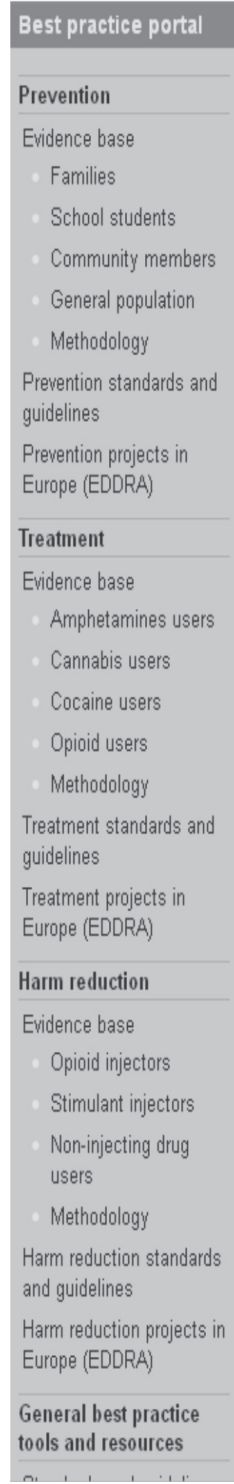

\section{Best practice portal}

The EMCDDA's Best practice portal is a resource for professionals, policymakers and researchers in the areas of drug-related prevention, treatment, harm reduction and social reintegration. The portal concentrates on illicit drugs and polydrug use and has a clear European focus. More information s

\section{Available modules}

The content in the portal is structured by thernatic modules. Each module below provides the current scientific evidence base for the corresponding type of intervention.

Prevention: families $\mid$ school students $\mid$ community members $\mid$ general population

Treatment: amphetamines users | cannabis users | cocaine users $\mid$ opioid users

Harm reduction: opioid injectors | stimulant injectors | non-injecting drug users

\section{Best practice resources \\ Standards and guidelines \\ This section compiles quality standards and guidelines for the implementation of practices \\ EDDRA \\ The Exchange on Drug Demand Reduction Action (EDDRA) provides real-life examples of evaluated practices in the European Union. \\ EIB \\ The Evaluation Instruments Bank $(E \mid B)$ is an online archive of freely available instruments for evaluating interventions. \\ OTHER RESOURCES \\ - Tools for evaluating practices}

News and recent updates

- Mav 2012: Evidence undates on prevention interventions for alcohol misuse for school-students, families and communities

- March 2012: Evidence updates on harm reduction interventions for opioid injectors »

- March 2012: Evidence updates on treatment interventions for opioid users »

- December 2011: European drug prevention quality standards published »

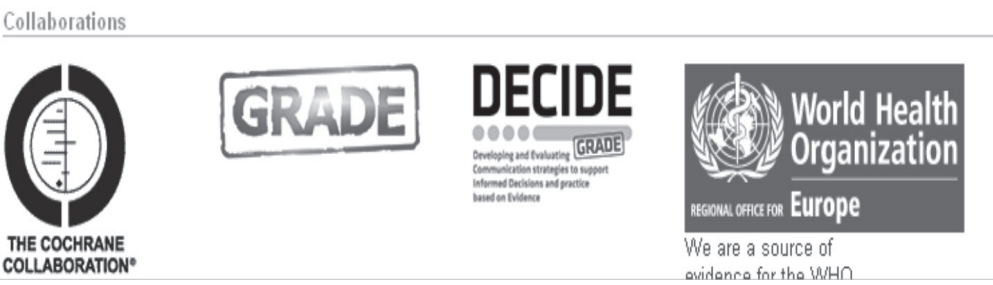

Figure 1. http://www.emcdda.europa.eu/best-practice.

The Best Practice Portal aims to be an information tool bringing together the synthesis of the available evidence, instruments to disseminate evidence, such as guidelines and standards, and implementation examples of practices across Europe in the field of drug demand reduction. Priority is given to the rigour of the methods. To achieve this objective we involved the top level research organizations in the field: first the Cochrane Drugs and Alcohol Editorial Group, the Grade working group (Guyatt et al., 2008) and more recently the European funded DECIDE Project ${ }^{2}$.

Summaries of evidence are made available in a user-friendly format and plain language information on the interpretation of the measures of effect supporting the evidence is provided, but we do not provide recommendations. In this way our readers are enabled to develop their own recommendations with the help of panels of local experts for appropriate adaptation, as indicated by the methodology of guidelines development (Grimshaw et al., 2004).

2 http://www.decide-collaboration.eu/
In general, no information is yet available on the impact of web-based point-of-care services on the actual practice improvement or change (Banzi, Moja, Pistotti, Facchini, \& Liberati, (2011a). With regard to the EMCDDA Best Practice Portal we only have crude rates of web accesses that are not informative. However there are plans to improve the monitoring of the portal's audience and a user survey is currently ongoing specifically for the EDDRA database.

Several are the challenges we are facing in our progression towards becoming an effective service and a platform for the exchange of best practices in drug demand reduction in Europe. We should be able to overcome language barriers. We are aware that the studies published in languages different from English are more difficult to be identified and enclosed in our synthesis of evidence. Of course we base our evidence modules on systematic reviews of evidence which are by definition enclosing all the relevant studies irrespectively of the Language and publication status. Still we are aware that the mentioned approach does not solve the so called publication bias risk. The inventory of documents makes available the existing guidelines in their national language and this may 
prevent their usability. Similarly we should be able to provide training and to promote exchanges and study visits. Some initiatives are being undertaken in collaboration with the Reitox Network of National Focal Points. Furthermore, thanks to the programmes developed by the European Commission Enlargement (available for acceding and candidate countries, potential candidates, and countries in the immediate vicinity of the EU, in North Africa, the Middle East and Europe) some progress has been made. Nevertheless more efforts are needed to let the dissemination activities becoming proactive.

The Best Practice Portal is just one output of a broader strategy of best practice promotion at the EMCDDA which, despite being in its early stages, has already been well received at international level with encouraging results. The EMCDDA Best Practice Portal has been in fact recognized as a source of evidence for the World Health Organization the Health Evidence Network ${ }^{3}$.

Europe is a continent rich in cultures, languages and theoretical approaches. Europe need to be able to learn from each other in the drug addiction field as they did in other areas. Paraphrasing Isaac Newton's quote "standing on the shoulders of giants" Europeans need to be able to stand over each others' shoulder to build a pyramid of knowledge, experience, lessons learned and enthusiasm.

\section{Acknowledgments}

We would like to acknowledge the support given by the Scientific Member Staff of the EMCDDA, the EMCDDA Scientific Committee, the Reitox Network of National Focal Points and the Cochrane Drugs and Alcohol Group.

\section{Declaration of interest}

Funding for the EMCDDA is provided by the European Union. The authors report no conflicts of interest

\section{References}

Banzi, R., Liberati, A., Moschetti, I., Tagliabue, L., \& Moja, L. (2010). A review of online evidence-based practice point-of-care information summary providers. Journal of Medical Internet Research, 12, 26. doi:10.2196/jmir.1288

Banzi, R., Moja, L., Pistotti, V., Facchini, A., \& Liberati, A. (2011a). Conceptual frameworks and empirical approaches used to assess the impact of health research: an overview of reviews. Health Research Policy and System, 9, 26. doi: 10.1186/1478-4505-9-26

Banzi, R., Cinquini, M., Liberati, A., Moschetti, I., Pecoraro, V. Tagliabue, L., \& Moja, L. (2011b). Speed of updating online evidence based point of care summaries: prospective cohort analysis. British Medical Journal, 343, d5856. doi: 10.1136/bmj.d5856.

Grimshaw, J. M., Thomas, R. E., MacLennan, G., Fraser, C., Ramsay, C. R., Vale, L., ... Donaldson, C. (2004). Effectiveness and efficiency of guideline dissemination and implementation strategies'. Health Technology Assessment, 8, 6 (Downloadable from http://www.hta. ac.uk/fullmono/mon806.pdf).

Guyatt, G.H., Oxman, A.D., Vist G., Kunz R., Falck-Ytter Y., AlonsoCoello P., ..., \& the GRADE Working Group, (2008). Rating quality of evidence and strength of recommendations GRADE: an emerging consensus on rating quality of evidence and strength of recommendations. British Medical Journal, 336, 924-926. doi: 10.1136/bmj.39489.470347.AD

Sackett, D. L., Rosenberg, W. M., Gray, J. A., Haynes, R. B., \& Richardson, W. S. (1996). Evidence based medicine: what it is and what it isn't. British Medical Journal, 312, 71-72.

3 http://data.euro.who.int/HEN/List-of-organizations.aspx 